\title{
Politicization of the Non-politicizable: The Collapse of the Ice Skating Rink in Bad Reichenhall on 2 January 2006
}

\subsection{Characteristics of the Case}

After heavy snowfall, the ice skating rink of the city of Bad Reichenhall collapsed on 2 January 2006, five minutes before its scheduled closure at 4:00 PM. ${ }^{1}$ The roof of the 33-year-old hall had not withstood the snow load. ${ }^{2}$ Fifteen people, twelve children between the age of 7 and 15 and three mothers, were killed by the falling debris of the roof. Thirty-four people were injured, six of them seriously. ${ }^{3}$

The actual ice rink was connected to a public indoor swimming pool by a central wing in which the changing room, a restaurant, baths and company apartments were located. The ice rink and indoor swimming pool formed a hall complex. The roof constructions had been executed separately for the ice rink and the swimming pool, on the day of the disaster

${ }^{1}$ Landgericht Traunstein, 2. Strafkammer, Verdict of 18 November 2008, 2KLs 200 JS $865 / 06$, paragraphs 95 and 233. Henceforth cited as LG 2008 RN plus number of Randnummer $(\mathrm{RN}=$ paragraph no. $)$.

${ }^{2}$ LG 2008 RN 96, 277.

${ }^{3}$ LG 2008 RN 66-90.

This chapter is the revised and translated version of the related case study in Wolfgang Seibel, Kevin Klamann and Hannah Treis: Verwaltungsdesaster. Von der Loveparade zu den NSU-Ermittlungen. Frankfurt/New York: Campus Publ. 2017, 113-158. The German original was authored by Kevin Klamann and Wolfgang Seibel.

(C) The Author(s) 2022

W. Seibel, Collapsing Structures and Public Mismanagement, https://doi.org/10.1007/978-3-030-67818-0_5 
only the roof construction of the ice rink collapsed. ${ }^{4}$ The relevant criminal investigations ${ }^{5}$ revealed considerable errors in the planning and construction of the ice rink which remained largely undetected and had to be regarded as the actual cause of the collapse. ${ }^{6}$ The maintenance of the building by the Bad Reichenhall city administration had also been neglected. Water ingress and condensation on the wooden support beams of the roof structure during operation of the hall did not cause the city, as the operator of the hall, to check the stability of the roof structure or take any other steps ${ }^{7}$ despite complaints from users. ${ }^{8}$ The City ignored also safety-relevant indications of defects in the hall complex which, however, were not connected to the collapse of the roof itself. ${ }^{9}$ The presiding judge at the Traunstein Regional (Repeal) Court characterized the behavior of the Bad Reichenhall city administration as being shaped by "sloppiness, ignorance, irresponsibility and scrupulousness". ${ }^{10}$

What the case has in common with other man-made disasters involving German governmental agencies is the absence of any investigation beyond criminal trial. No expert commission, no parliamentary investigation committee nor any otherwise independent investigation was undertaken. Among the four cases of collapsed bridges and buildings caused by public

\footnotetext{
${ }^{4}$ LG 2008 RN 32-33.
}

${ }^{5}$ The judicial processing of the catastrophe of 2 January 2006 began with a criminal trial before the Traunstein Regional Court or Landgericht. This ended on 18 November 2008 with the conviction of an engineer involved in the construction. A project manager involved in the construction and an expert who had issued a positive certificate for the hall roof in 2003 were acquitted of negligent manslaughter charges. An appeal trial filed by the Public Prosecutor with the Traunstein Regional Court and the joint plaintiffs regarding the expert's acquittal ended on 12 January 2010 with the revocation of the acquittal and referral to the Traunstein Regional Court (Federal Supreme Court, Verdict of 12 January 2010, 1 StR 272/09). A different chamber of the Regional Court confirmed the first instance acquittal of the expert by Verdict of 27 October 2011 (Landgericht Traunstein, 6. Strafkammer, Urteil vom 27.10.2011, 6KLs 200 JS 865/06 (3)).

${ }^{6}$ LG 2008 RN 102-135.

${ }^{7}$ LG 2008 RN 139, 229, 452.

${ }^{8}$ LG 2008 RN 190, 391-2, 462; Landgericht Traunstein, 6th Strafkammer, Verdict of 27.10.2011, 6KLs 200 JS 865/06 (3), paragraph 271. Cited below as LG $2011+$ Randnummer (number of paragraph).

${ }^{9}$ LG 2011 RN 272-277.

10 "Schlamperei, Ignoranz und Skrupellosigkeit", Welt Online, 27.10.2011, http://www. welt.de/vermischtes/weltgeschehen/articlel3684199/Schlamperei-Ignoranz-undSkrupellosigkeit.html, last accessed 23 March 2017. In this chapter, all quotes from German originals are author's translations. 
administration mismanagement that are analyzed in the present volume, the German case with a death toll of twelve children and three mothers accompanying them to a pastime entertainment is the only one without official acknowledgment of responsibility.

\subsection{Facts of the MatTer}

The construction of the hall complex on behalf of the city of Bad Reichenhall began in 1971. The part of the hall that collapsed in 2006 was used as an ice skating rink in winter, otherwise as a tennis hall. ${ }^{11}$ The hall went into operation in the Fall of $1973 .{ }^{12}$ A subcontractor working on behalf of the general contractor was responsible for the planning, manufacture and erection of the roof construction. ${ }^{13}$ The subcontractor had delegated these works to a civil engineer for whom, according to his

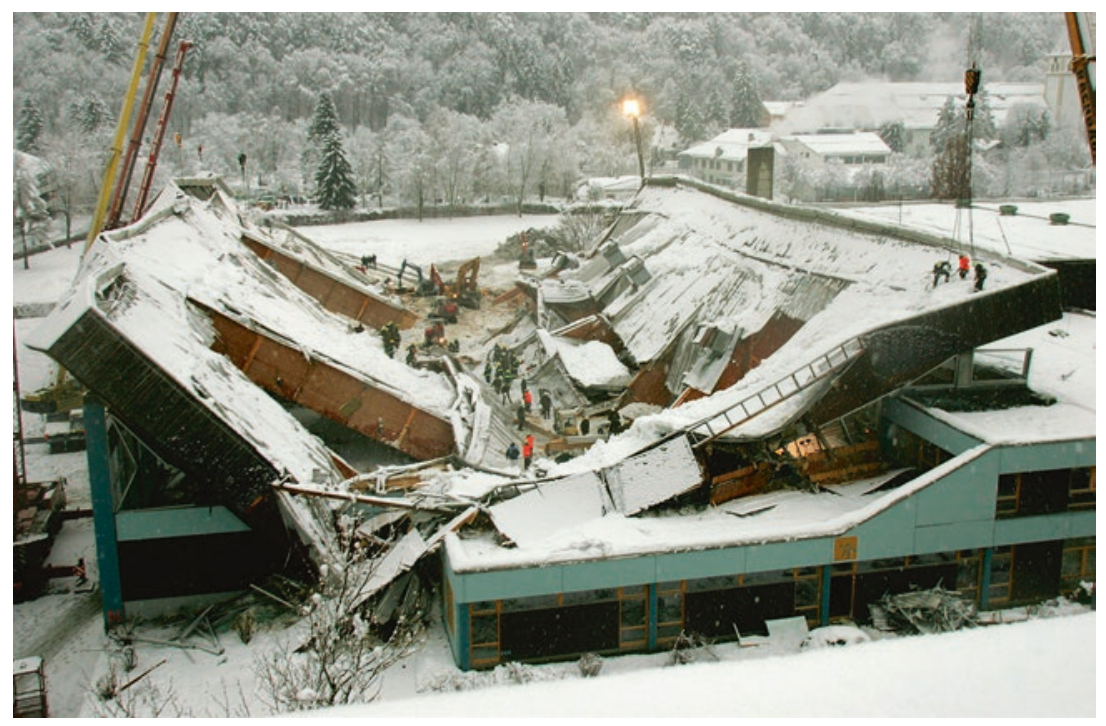

Illustration 5.1 Bad Reichenhall Ice Skating Rink after the collapse of 2 January 2006 (Deutsche Presseagentur / Picture Alliance, media no. 38145505, license 212103591)

${ }^{11}$ LG 2008 RN 56, 292.

${ }^{12}$ LG 2008 RN 277.

${ }^{13}$ LG 2008 RN 44. 
statement before the Traunstein Regional Court, the intended construction method was "new territory", so that he had to rely on the assistance of yet another engineer involved in the construction. On 18 November 2008 , the civil engineer who was mainly responsible for the construction errors was sentenced to 18 months imprisonment on probation for negligent manslaughter and negligent bodily injury. A project manager was acquitted. ${ }^{14}$ A civil servant of the Bad Reichenhall city administration who, according to the public prosecutor, had been responsible for supervising the construction of the hall complex, was indicted but fell seriously ill during the trial so that the criminal proceedings against him had to be suspended. The trial against a master carpenter involved in the production of faulty roof racks was also discontinued after his death. ${ }^{15}$

The negligent attitude of the city administration was partly driven by an exemplary conflict of interests. The city was both the owner of the hall and the supervisory authority of building safety. The quest for saving taxpayer's money and the necessity to ensure the safety of infrastructure began to collide when maintenance costs increased and urban planning ideas of the Lord Mayor envisaged abandoning the hall complex altogether. So the building authority was exposed to the Lord Mayor's expectation not to invest too much efforts and money into the maintenance, let alone renovation, of the hall complex which comprised both the ice rink and an indoor swimming pool. According to the Lord Mayor's own admission before the Traunstein Regional Court, this culminated in the downright obstruction of a municipal parliament decision to substantially renovate the hall at estimated costs of 5.5 million Euros.

An expert who had examined the roof construction of the ice skating rink without in-depth structural analyses in 2003 and nonetheless certified it to be in good condition was acquitted by the Traunstein Regional Court in 2008. The acquittal was annulled by the Federal Supreme Court in 2010 , inter alia on the grounds that it was necessary to examine whether the expert opinion was a "carte blanche" for the City of Bad Reichenhall in the form of an inappropriate finding. ${ }^{16}$ After referral of the case, the Traunstein Regional Court confirmed the acquittal. The Court could not clarify whether the expert had been explicitely commissioned to examine

${ }^{14}$ LG 2008 RN 1-10.

${ }^{15}$ LG 2011 RN 7, 30.

${ }^{16}$ Bundesgerichtshof, Verdict of 12.01.2010, 1 StR 272/09, paragraph 1 and paragraphs 81 to 86 . Cited below as BGH 2010. 
the roof construction and, in view of these doubts, did not see this defendant in a guarantor position with regard to the actual safety of the roof construction. ${ }^{17}$ It was a telling detail when the Regional Court stated that even if a related contractual arrangement had existed, "the responsible city administration would not have taken any measures that could have prevented the accident of 02.01.2006"18 in light of the sloppy and negligent attitude of the municipality in general.

The death of twelve children and three mothers who lost their lives under the collapsing roof of the Bad Reichenhall ice rink on 2 January 2006 was not the result of a tragic chain of unfortunate circumstances but of the failure of the Bad Reichenhall city administration to meet elementary professional and ethical requirements. The Lord Mayor of the city and leading officials in the building authority pursued their own urban planning ambitions at the expense of the safety of the hall users and the operational staff. This happened despite warnings of water ingress that had been noticed for years but were ignored by the city administration. While these water infiltrations did not cause the collapse, a risk-conscious reaction on the part of the city administration would have commissioned a thorough investigation into their origin which in turn, according to all likelihood, would have uncovered the basic construction and design errors of the roof that caused the collapse of the hall on 2 January 2006.

\subsubsection{Design and Construction Errors}

The civil engineer of the subcontractor commissioned with the planning, manufacture and erection of the roof construction made several serious mistakes in the structural calculations, so that the actual load capacity of the roof construction was considerably lower than shown in the calculations. ${ }^{19}$ In Court, the relevant engineer stated that he had submitted his calculations for review to a consultancy firm also working for the general contractor where no objections were raised. Subsequently, the relevant calculations were forwarded to a structural engineering expert appointed by the general contractor. ${ }^{20}$

\footnotetext{
${ }^{17} \mathrm{LG} 2011 \mathrm{RN} 251$.

${ }^{18} \mathrm{LG} 2011$ RN 3.

${ }^{19}$ LG 2008 RN 98, 266-267.

${ }^{20}$ LG 2008 RN 45, 176, 242.
} 
According to the findings of the Traunstein Regional Court, the roof construction was under designed. Its basic elements were ten 48 -meterlong wooden girders. In contrast to the indoor swimming pool, where these girders were supported by intermediate posts, they had to span a distance of 40.5 meters in the ice rink without such support. ${ }^{21}$ According to the Court, girders of this length represented an unusual construction. ${ }^{22}$ In order to ensure sufficient load-bearing capacity of the 48-meter-long girders, they had to be manufactured with a width of 2.87 meters. This was not in compliance with existing regulation stipulating a maximum width of 1.20 meters. In addition, the girders were designed in a hollow box cross-section which deviated from the building permit. ${ }^{23}$ This would have required a special permit which the civil engineer failed to apply for. ${ }^{24}$ In Court, he stated that he had not been aware of the permit requirement. ${ }^{25}$ During the manufacture of the girders by two more subcontractors, more errors occurred the most serious of which was the use of urea resin glue with insufficient water resistance when assembling the wooden boxes of the girders. ${ }^{26}$

\subsubsection{Unbureaucratic Sloppiness}

A particularly serious aspect of mismanagement that directly impacted on the ultimate collapse of the ice rink roof was the absence of proper documentation of the relevant structural engineering and related calculations. ${ }^{27}$ After the disaster of 2 January 2006, investigators did find a folder with a sticker "Statik Eishalle" (Statics, Ice Rink) but it was empty. ${ }^{28}$ The absence of proper documentation turned out to be crucial when, in 1977, the city administration of Bad Reichenhall decided to vitrify the upper part of the ice rink. The reason was the noise pollution of the neighborhood caused by the initial open construction. The vitrification had already been included as an option in the original construction planning and had also been taken into account by the architect. However, in the course of the vitrification,

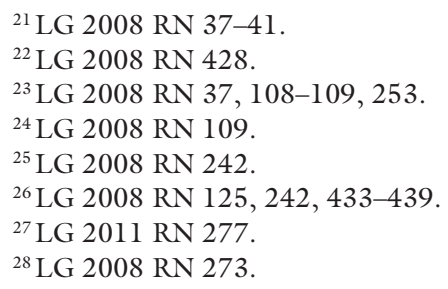


four exhaust air systems were installed on the roof of the ice rink in anticipation of the increased humidity in the now enclosed hall. The exhaust air systems increased the weight of the roof load by 2300 kilograms. The city administration failed to initiate a building permit procedure to have the statics of the construction checked under the conditions of the increased roof load. ${ }^{29}$

During the operating time of the ice rink there were repeated water ingresses and condensation on the girders. Rain water pipes were underdimensioned so that water also penetrated the box girders during overflow. In addition, an insufficient roof pitch led to more water ingress. These deficiencies had already been identified in 1975 but work to remedy them in 1975 and 1976 did not eliminate the issue. On the wooden girders, water run-off tracks were already noticeable in the late $1970 \mathrm{~s} .{ }^{30}$ Both the operating staff of the ice rink and the local ice hockey club drew the city administration's attention to the water infiltrations. ${ }^{31}$ Witnesses testified before the Traunstein Regional Court that the official in charge at the City Council had just replied laconically "that structure survives us all". ${ }^{32}$ The board of the local ice hockey club stated that it had informed the Lord Mayor, but that he had merely pointed to other priorities at the time. ${ }^{33}$ Buckets had to be put in the hall on a regular basis to collect water dripping from the roof. ${ }^{34}$ In April 2005, the organizer of a flea market held in the hall contacted the hall manager pointing to water intakes-estimated at more than 750 liters-during the flea market alone. ${ }^{35}$

The Traunstein Regional Court, already in its first ruling of 2008, confirmed that the city Bad Reichenhall in dealing with the humidity problem displayed a "persistent breach of duty". ${ }^{36}$ Since the late 1970s, the City had not carried out or initiated any special refit or renovation or in-depth

${ }^{29}$ LG 2008 RN 57-58, 436, 462.

${ }^{30}$ LG 2008 RN 60-63.

${ }^{31}$ LG 2008 RN 380-392.

${ }^{32}$ LG 2008 RN 389.

${ }^{33} \mathrm{LG} 2008$ RN 391.

${ }^{34}$ LG 2008 RN 62, 385, 390.

35 "E wie Eishalle", in: DER SPIEGEL 14/2006, p. 58.

${ }^{36}$ LG 2008 RN 462: In the first proceedings, the Traunstein Regional Court discussed breaches of duty by third parties and their possible influence on the responsibility of the three defendants. The Court did not make a final assessment of the actions or omissions of the Bad Reichenhall municipal administration as criminal charges against municipal officials were ultimately dropped. 
inspection of the hall. ${ }^{37}$ No protective coating or special inspection of the roof structure was commissioned either although, according to the Traunstein Regional Court, "there would have been reason to do so due to the frequent water infiltrations and the visible water drainage traces on the girders $[\ldots] " .38$

\subsubsection{Acknowledged Yet Unaddressed Safety Issues}

The general attitude of the City administration regarding the hall complex changed around the turn of the millennium. The driver was an EU Directive which necessitated costly renovation measures for the indoor swimming pool technology, in particular the replacement of the water treatment facility. An annual operational deficit of 600,000 to 700,000 Euros was also taken into consideration. ${ }^{39}$ This prompted the Bad Reichenhall municipal authorities to commission a series of expert reports to estimate the costs of modernizing the indoor swimming pool and renovating the entire hall complex. ${ }^{40}$ As early as 2001, an expert report was commissioned on the roof structure of the swimming pool hall. ${ }^{41}$ In February 2002, estimates of refit costs, including sanitary facilities and bathing equipment, were obtained. In October 2002, a study was carried out on electrical installations with findings also on fire protection. In May and July 2003, expert opinions followed on the indoor swimming pool. Finally, a summary study was carried out in March $2004 .{ }^{42}$

The short report from 2001 found serious defects in the structure of the roof of the indoor swimming pool that did apparently not affect the roof of the ice rink in the same hall complex. The expert warned that "the secondary construction of the indoor swimming pool roof was at risk of collapsing, as was the canopy roof of the entrance area to the ice rink and indoor swimming pool" ${ }^{\prime 3}$ where glued laminated timber beams were massively weakened. ${ }^{44}$ Both assessments were confirmed by the 2003 study of a civil engineer who had already authored the short expert report of

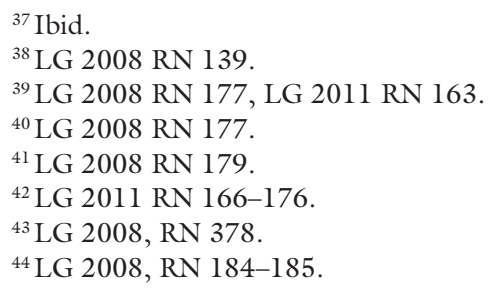


2001. ${ }^{45}$ The experts consulted by the Traunstein Regional Court in 2008 repeated the obvious: That the defects in the roof construction of the indoor swimming pool and the canopy, which had been determined by the expert at the time, posed a "danger to life and limb" to the users of the indoor pool due to falling parts. ${ }^{46}$

Despite the disturbing reports, the City authorities did not initiate any countermeasures. The canopy of the hall complex was demolished in 2005. However, this only happened after parts had fallen from it and thus endangered the life and limb of the hall users indeed. ${ }^{47}$ While the City administration stated in the trial before the Traunstein Regional Court that it had requested the operating staff of the hall complex to monitor the defects, staff members declared-"credibly", in the opinion of the Regional Court - that they had never been informed of the results of the expert reports commissioned by the City. Rather, the poor condition of the canopy had been discovered by chance and only makeshift metal supports had been attached. ${ }^{48}$

The very expert who had determined the serious defects in the secondary structure of swimming hall roof and the canopy of the hall complex pointed out in his short report of 2002 that the pipe systems of the swimming hall were so badly corroded that soaking of the wooden construction could occur. The expert recommended a refit which, however, the City did not commission. ${ }^{49}$ That same year, the city of Bad Reichenhall responded to warnings regarding fire protection in the indoor swimming pool only by renewing the fire alarm system. Other serious deficiencies in concerning fire protection were not taken into account. ${ }^{50}$

\subsubsection{Mobilizing Recognizably Insufficient Expert Opinions}

Also in 2002, the building authority of the City of Bad Reichenhall contacted an architect asking for an expert opinion on the renovation costs of

\footnotetext{
${ }^{45}$ Ibid., LG 2011 RN 207-209.

${ }^{46}$ LG 2008 RN 378.

${ }^{47}$ LG 2008 RN 185, 378.

${ }^{48}$ LG 2011 RN 275.

${ }^{49}$ LG 2008 RN 187-8, LG 2011 RN 176.

${ }^{50}$ LG 2011 RN 276. Also with regard to a "highlighted in bold" (LG 2008 RN 401) danger of a hanging wooden ceiling crashing in the indoor swimming pool in the expert report of February 2002, the City only reacted with remedial work after a piece of wood had actually fallen down.
} 
the hall complex. During an initial inspection, the architect determined that an expert opinion only made sense on the basis of an in-depth inspection of the hall complex by an experienced civil engineer. The architect also based his judgment on concrete damage visible to the naked eye and traces of water on the beams of the roof structure of the ice rink. He informed the building authorities of this in writing on 9 July $2002 .{ }^{51}$ "Credibly", according to the assessment of the Traunstein Regional Court, the architect recommended "a deeper investigation of the primary structure of the ice hall roof as well". ${ }^{52}$ The architect, who testified as a witness before the Traunstein Regional Court, stated that once he had submitted his report the City Council had not contacted him any further. ${ }^{53} \mathrm{He}$ said he had been under the impression that the City found the scope of the investigations he had proposed "too large". ${ }^{54}$

Experts consulted by the Traunstein Regional Court stated that the cost of comprehensive inspection of the roof structure would have amounted to approximately 30,000 Euros but certainly not less than 20,000 Euros. ${ }^{55}$ The expert opinion contract was finally awarded on 27 January 2003 to a civil engineer on the basis of a mere 3000 Euros fee. ${ }^{56}$ In his report, he stated:

The supporting structures-both wooden and reinforced concrete-of the entire ice rink are in a generally good condition. Only water stains can be found in the wooden structure due to irregularities/water ingress from the roof drainage system. However, these have no influence on the quality or the load-bearing capacity of the supporting structure. ${ }^{57}$

As a defendant before the Traunstein Regional Court, this expert stated that the relevant official of the City's building authority had reported to him during a joint inspection of the hall "that there had only been one water ingress". ${ }^{58} \mathrm{He}$ had just been asked for a "rough cost estimate" and

\footnotetext{
${ }^{51}$ LG 2008 RN 190.

${ }^{52}$ LG 2011 RN 271.

${ }^{53}$ LG 2008 RN 190.

${ }^{54}$ LG 2008 RN 375.

${ }^{55}$ LG 2008 RN 411; LG 2011 RN 271.

${ }^{56}$ LG 2008, RN 169, 206.

${ }^{57}$ LG 2011 RN 129.

${ }^{58}$ LG 2008 RN 336.
} 
was not supposed to investigate the roof structure of the ice rink in depth. ${ }^{59}$ In the appeal verdict of 2011 , the Traunstein Regional Court noted that the relevant City officials should have realized that an expert report for just 3000 Euros could not result in an in-depth inspection of the roof structure anyway. ${ }^{60}$

The consulted expert examined only one of the wooden girders at close range and only inspected the other girders through the telephoto lens of his camera. The Traunstein Regional Court stated that signs of weaknesses in the glued joints of the roof structure could have been detected in close examination at the time, i.e. in 2003, and, according to all likelihood, would have prompted the consulted expert to recommend an in-depth inspection. ${ }^{61}$ Such an inspection, in turn, would have necessarily included a review of the construction documents. As it turned out after the disaster of 2 January 2006, however, those documents were undetectable. ${ }^{62} \mathrm{It}$ remained undetermined whether documentation of the structural design of the hall and related calculations analysis could no longer be found or had never existed in the files of the building authority. ${ }^{63}$

In the opinion of the Traunstein Regional Court in its final decision of 2011 the Bad Reichenhall City administration had not deliberately intended to extend the service life of the hall without costly remedying of defects. ${ }^{64}$ On the other hand, the verdict of the Regional Court on the attitude of the Bad Reichenhall building authority was all the more devastating: In the opinion of the Court, even more thorough investigations, including an appraisal of the structural design of the ice skating rink roof which could have resulted in further recommendations, "with a probability bordering on certainty" would not have prompted the responsible officials of the City administration to take any measures that ultimately would have prevented the accident. ${ }^{65}$ And, quite ironically, for this reason the

${ }^{59}$ LG 2011 , RN 231.

${ }^{60}$ LG 2011 RN 244, see also LG 2008 RN 353.

${ }^{61}$ LG 2008 RN 208, 358-359.

${ }^{62}$ While the Traunstein Regional Court assumed in 2008 that the review of the original construction documents would only have become necessary in the course of an in-depth inspection that did not take place, a different Chamber of the same Court in 2011 assumed that the defendant had had the obligation to review the original documentation anyway. Cf. LG 2008 RN 361, LG 2011 RN 264.

${ }^{63} \mathrm{LG} 2011$ RN 262.

${ }^{64}$ LG 2011 RN 254-6.

${ }^{65} \mathrm{LG} 2011 \mathrm{RN} 160$. 
consulted expert, according to the Court, could not be held accountable for the consequences of his obviously misleading report on the structural conditions of the hall roof.

In March 2004, the city of Bad Reichenhall commissioned a summary report to be drawn up which estimated the costs of restoration of the hall complex at $\mathbf{5 . 5}$ million Euros and at the same time doubted the sense of such a measure. ${ }^{66}$ This report also contained a reference to the fact that there was no separate estimate of the renovation costs for just the roof construction of the ice rink. ${ }^{67}$

\subsubsection{An Obstructed Municipal Parliament Decision and the Path to Disaster}

The Bad Reichenhall Stadtrat — the municipal parliament-finally decided on 14 June 2005 to preserve and renovate the hall complex with the ice skating rink and indoor swimming pool. This decision was deliberately ignored by the City administration, as the Lord Mayor had to admit in Court. The Mayor, instead, preferred the closure of the hall complex and to envisage a new facility with a sports pool to a spa and wellness center that was in the making anyway elsewhere in the city. ${ }^{68}$ In fact, that plan was realized later on. ${ }^{69}$ This did not alter the fact that the immediate implementation of the City Council's decision or, alternatively, the shut-down of the ice skating rink would have saved the lives of twelve children and three mothers killed when the roof of the hall collapsed on 2 January 2006. The Traunstein Regional Court stated in this regard:

On 14.06.2005, the city council decided that the entire complex should be renovated. It commissioned the administration to create a renovation concept on the basis that both the ice skating rink and the indoor swimming pool would be preserved, but the indoor swimming pool would no longer be used as a public swimming pool, but as a pure sports pool. Contrary to this decision of the city council, the administration did not make any effort to implement this decision. Until the collapse of the hall on 02.01.2006 nothing was done in this respect. Rather, the Lord Mayor continued to

\footnotetext{
${ }^{66} \mathrm{LG} 2011 \mathrm{RN} 173$.

${ }^{67}$ LG 2011 RN 271.

${ }^{68}$ LG 2011 RN 270.

${ }^{69}$ Ibid.
} 
favour another solution, namely the incorporation of a sports pool into the new spa and the demolition of the entire hall complex. ${ }^{70}$

After heavy snow fall, the building manager of the ice rink took samples of the snow cover on the roof on the morning of 2 January 2006 and determined a snow load of 166 kilograms per square meter. ${ }^{71} \mathrm{He}$ had at his disposal only a handwritten note according to which the load-bearing capacity limit was 175 kilograms per square meter. The manager therefore saw no reason for an immediate evacuation and shut-down of the ice rink. Court experts later assessed that at the time of the measurement the roof load had presumably not exceeded 146 kilograms per square meter and that the correct load-bearing capacity limit was 150 kilograms per square meter-under the condition of a flawless roof construction. ${ }^{72}$ The handwritten note routinely used was a copy made by the operating personnel which, according to Court experts, came from "an outdated design assessment for a completely different roof construction". ${ }^{73}$

At 2:44 PM a weather warning of the German Weather Service announcing more heavy snowfall to be expected in the region from 3:00 PM on reached the manager of the hall. This prompted him to consult with the building authority of the city administration the result of which was the decision to close the ice skating rink prematurely at 4:00 PM. It was understood that the snow load on the roof should be reduced the next day according to common practice under such conditions. ${ }^{74}$ Around 3:30 PM, according to witnesses, a cracking bang was to be heard in the ice skating rink, coming from the roof, which did not trigger any consequences.

At 3:55 PM the roof of the skating rink suddenly collapsed. The sequence of the collapse remained unclear in detail. Two scenarios were considered. In both, the failure of the wooden roof girder beams was assumed as the trigger factor. Both scenarios assumed that the failure was caused by the yielding of adhesive joints due to the constant moisture and the swelling and shrinking of the wood of the roof structure. In one of the scenarios, the urea resin glue used was particularly highlighted. It was

${ }^{70}$ LG 2011 RN 214-215.

${ }^{71}$ LG 2008 RN 94.

${ }^{72}$ LG 2008 RN 236-238; LG 2011 RN 279.

${ }^{73}$ LG 2011 RN 279.

${ }^{74}$ LG 2008 RN 95, General Prosecutor's Office Munich, refusal of 21.08.2007, p. 6. The document was temporarily available at: http://reichenhaller-pranger.de/resources/generals taatsanwalt+m\$C3\$BCnchen+29.08.07.pdf, last accessed on 27 February 2013. 
assumed that the urea resin glue, which is not sufficiently water-resistant, triggered the failure of one of the girders. In both scenarios, after the failure of one girder beam, the rigid connections between the remaining beams, which were also defective and weakened due to age, triggered a kind of chain reaction that led to the collapse of the entire roof. ${ }^{75}$

\subsection{Case Analysis}

\subsubsection{Turning Points and Critical Junctures}

If there was one critical juncture on the pathway to the catastrophe of 2 January 2006 then it was the decision of the Bad Reichenhall building authority of 27 January 2003 to forego a special inspection of the roof structure of the ice rink. An architect consulted by the city had suggested such an inspection in 2002. According to the Traunstein Regional Court, the inspection alone would have cost no less than 20,000 Euros. ${ }^{76}$ The building authority decided, however, to seek the considerably cheaper expert opinion of a local civil engineer instead. According to the findings of the Traunstein Regional Court in verdicts of 2008 and 2011, this expert opinion could not provide reliable information about the actual condition of the roof construction of the ice rink. ${ }^{77}$ If, on the other hand, the City administration had followed the recommendation of the previously consulted architect and had had a special examination of the roof construction carried out accordingly, the fundamental construction faults of the roof would have been determined "with a probability bordering on certainty", according to the Regional Court. ${ }^{78}$ Knowing the deficiencies of the ice rink, it seems very likely that the catastrophe of 2 January 2006 would have been averted by timely renovation measures or at least an earlier shutdown on the day of the disaster. The reason why the recommendation of

\footnotetext{
${ }^{75}$ With regard to the errors committed by the civil engineer convicted in 2008 , the Regional Court 2008 declared: "All three established breaches of duty of the defendant G, construction contrary to the building authority approval, inadequate static calculation and careless monitoring of the manufacturing process were causal for the collapse. The existence of only one of the assumed breaches of duty in each case would possibly not have led to the collapse on 02.01.2006, but the simultaneous existence of these errors did have." LG 2008 RN 450.

${ }^{76}$ LG 2011 RN 266, 271.

${ }^{77}$ LG 2008 RN 190; LG 2011 RN 265-272.

${ }^{78}$ LG 2011 RN 266.
} 
the architect consulted in 2002 should have been taken seriously was the well-known signs of construction defects in the form of water ingress, the Regional Court stated. ${ }^{79}$

The extent of responsibility of the relevant officials of the Bad Reichenhall municipal administration is underlined by two further circumstances. Not only was an in-depth inspection of the roof construction omitted, but the City administration, the Lord Mayor in particular, also ignored the decision of the Bad Reichenhall municipal parliament of 14 June 2005 to have the hall complex completely renovated. ${ }^{80}$ After the City administration had already two years earlier renounced on an in-depth inspection of the roof structure, which had been recommended to it by an expert, the attitude of not investing any major funds in further inspections became entrenched. This attitude did not change at all when the municipal parliament decided, in June 2005, to have the hall structure entirely renovated which was contrary to the interests of the administration in closing down and dismantling the hall complex instead.

An antecedent turning point that changed the disposition of the City administration was the turn of the millennium ${ }^{81}$ when a new EU Directive for infrastructure standards caused doubts as to whether the hall complex as such could have an economically viable future at all. This provided an incentive for cost reduction in case of any renovation measures. Still, however, it was a serious omission that the Reichenhall City administration did not pay thorough attention to the water ingress and to the advice of the architect consulted in 2002 to conduct an in-depth inspection of the roof construction of the ice rink (Fig. 5.1).

\footnotetext{
${ }^{79}$ LG 2008 RN 139.

${ }^{80}$ The recommendation to take measures to estimate the renovation costs for the roof of the ice rink, which was found in the summary report of March 2004 (LG 2011 RN 248, 271 ), suggests that a more detailed inspection of the roof could have been expected for the renovation planning if the administration had actually wanted to carry out the renovation itself (LG 2011 RN 248, 271). The city did not react to this recommendation either, as the Traunstein Regional Court stated: "Even when Witness L. in his 2004 study—as he credibly described it-pointed out urgently to the obviously unexamined and unevaluated roof construction, there was still no reaction on the part of the city administration, neither the commissioning of an additional study nor a possible consultation with the defendant." LG 2011 RN 248.

${ }^{81}$ LG 2011 RN 163.
} 


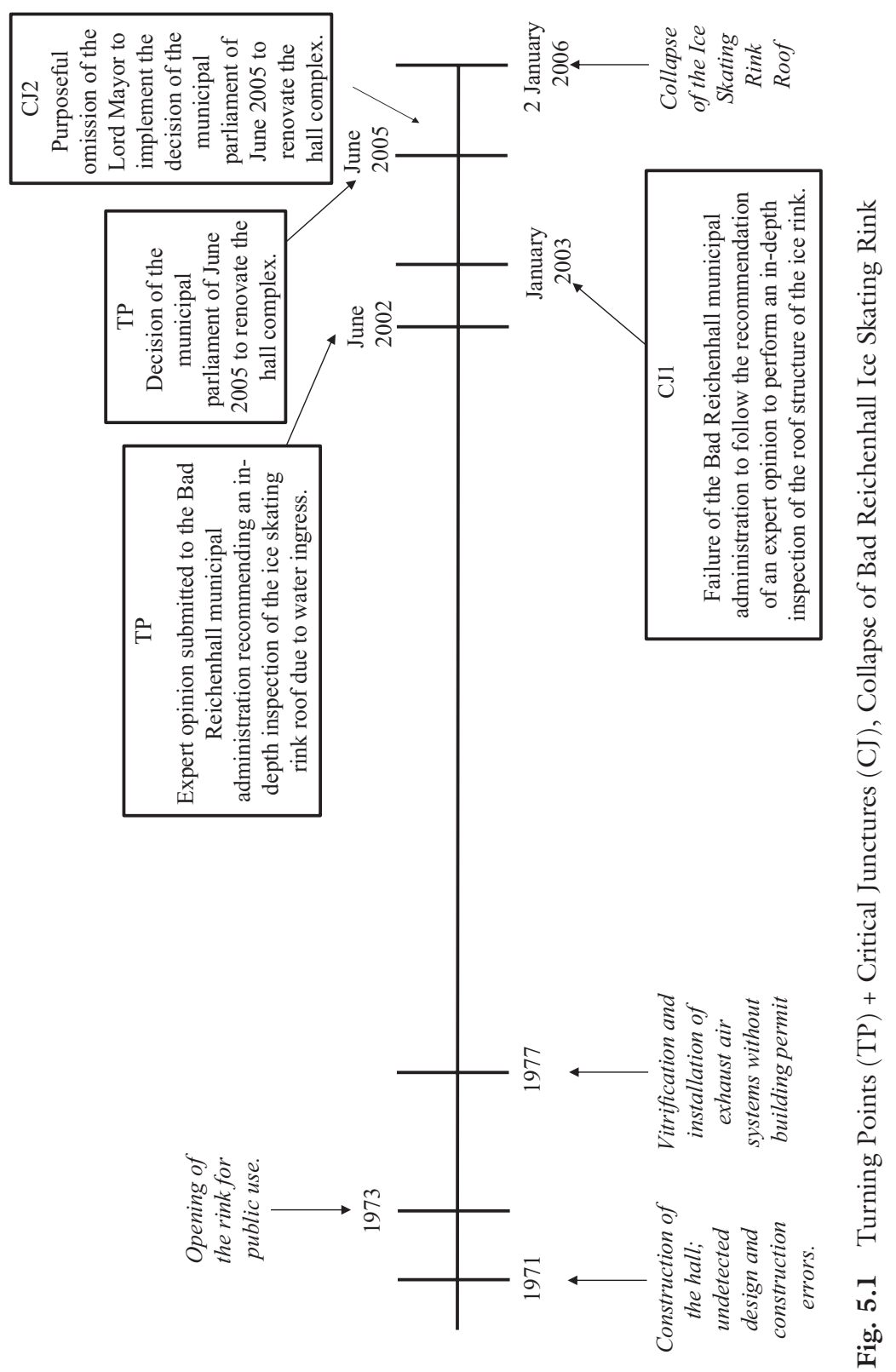




\subsubsection{Contributing Factors and Necessary Conditions}

The collapse of the skating rink in Bad Reichenhall was the cumulative effect of several independent causal factors, yet it did not result from the proverbial chain of unfortunate circumstances. It was not the circumstances that triggered the catastrophe of 2 January 2006 but decisions taken by officials of the Bad Reichenhall City administration who themselves could not fully anticipate the consequences of their decisions or omissions but nevertheless failed to act mindfully and with the necessary sense of responsibility. This pertains to the original design and construction errors of 1973, the faulty initial inspection and approval of the roof structure, the way in which the vitrification of the ice rink was carried out including the installation of exhaust air systems in 1977, the disregard of an expert's recommendation of 2002 as well as the continued indications by users and operating personnel that water was entering the ice skating rink, the non-compliance with the municipal parliament's decision of June 2005 to renovate the hall complex and the decision making concerning the closure of the ice skating rink on the day of the accident itself.

The Bad Reichenhall ice rink would not have collapsed if it had not been for the construction faults, but these faults could have been recognized in due time and they could have been rectified. ${ }^{82}$ Carelessness of supervision and maintenance was another necessary condition for the later collapse of the hall, but it alone would not have triggered the collapse given the original construction defects which were diagnosed by the experts consulted by the Traunstein Regional Court as the ultimate cause ${ }^{83}$ In addition, there was insufficient monitoring of the manufacturing process of the girder beams, so that their faulty construction and incorrect gluing with its detrimental effect given the high moisture load of the ice rink were not prevented. The civil engineer in charge did not seek the special permit required for girder constructions of the chosen type. The special permit, if granted, would have been based on a review of the structural design and on conditions whose fulfillment would have prevented, according to all likelihood, the construction faults of the roof. In their mutually reinforcing interaction, these errors were a necessary condition for the collapse of the hall on 2 January $2006 .{ }^{84}$

${ }^{82}$ See the assessment of the Landgericht Traunstein: LG 2008 RN. 98, 452.

${ }^{83}$ LG 2008 RN 98.

${ }^{84}$ This was also the evaluation of the Landgericht (Regional Court) Traunstein, cf. LG 2008 RN 109, 450. 
After completion of the construction works in 1973, the city of Bad Reichenhall building authority had to decide on the final approval of the hall in terms of compliance with existing regulation. After the disaster of January 2006, it turned out that proper documentation of the relevant structural engineering and related calculations were missing. The relevant folder in the building authority did exist but it was empty. It remained unknown whether calculations of the structural design of the ice skating rink roof had been performed at all, which was highly probably though. ${ }^{85}$ Therefore, the mere fact of the building permit issued in 1971 could only count as a relevant causal factor if it had actually taken place in the absence of the required review of the structural design and related calculations. In cross-examination before the Traunstein Regional Court, witnesses and experts stated that this kind of omission would be practically inconceivable. ${ }^{86}$

An additional risk factor was the vitrification of the ice rink carried out in 1977 which inevitably increased the level of humidity in the hall, so that in the same year an exhaust air system was installed with the necessary equipment placed on the roof of the hall. This double measure-vitrification and installation of the exhaust air system - was problematic on the one hand because an insufficiently moisture-resistant urea resin glue had been used to erect the wooden structure of the roof and, on the other hand, because the additionally installed exhaust system increased the roof load by a total of 2300 kilograms. With regard to the vitrification itself, the city of Bad Reichenhall acted flawlessly. This measure was already envisaged in the building contract of 1971, so the city could assume that the subsequent vitrification had been taken into account in the construction of the roof itself.

The situation was different for the decision to install the exhaust air system. According to the Traunstein Regional Court, the resulting increase in the roof load was not the cause of the collapse of the hall roof because the snow load that occurred on 2 January 2006 would have had to be carried in the absence of construction faults regardless of the dead weight of the exhaust air systems. ${ }^{87}$ Irrespective of these construction-physical aspects, however, a breach of duty on the part of those responsible in the Bad Reichenhall city administration lay in the fact that no building permit

${ }^{85}$ LG 2008 RN 274, 290, 441.

${ }^{86}$ LG 2008 RN 275.

${ }^{87}$ LG 2008 RN 100. 
procedure had been initiated for the installation of the exhaust air system and that, despite the increase in the roof load, no special inspection and, if necessary, reinforcement of the roof structure had been carried out. ${ }^{88}$ If such an adjustment had taken place, the absence of documentation on the structural design and related calculations would have been noticed, the Traunstein Regional Court stated ${ }^{89}$ In this case, it is highly probable that the absence of a load-carrying test certificate for the stability of the entire roof construction would have been detected as well. Or, if at that time, i.e. 1977, complete documentation had still been available in the files the City administration it would at least have had precise information about the load-carrying capacity itself. Either way, a proper installation and approval of the exhaust air system would have led to a review of the relevant documentation.

A stronger counterfactual scenario can be assumed under the premise that no documentation was available and that this very fact would have been detected in a certification process in accordance with due diligence standards when the vitrification of the hall in 1977 was in the making. Continued operation of the hall in the knowledge that there was no verifiable documentation of the building's structural design would have been inconceivable. To that extent, the absence of a verification of the design can be defined a further necessary condition for the collapse of 2 January 2006.

Similar to the vitrification of the ice skating rink and the resulting installation of the exhaust air system, the Bad Reichenhall city administration's failure to react to the water ingress registered during almost the entire time the rink was in operation was also significant. As an isolated factor, the apparent leaks in the hall roof were "not the cause" of the collapse of the hall roof according to the Traunstein Regional Court. ${ }^{90}$ However, the fact that those responsible in the Bad Reichenhall municipality simply ignored the water ingresses repeatedly admonished by hall users was, in the opinion of the Court, a breach of duty anyway. ${ }^{91}$ The monitoring of the roof by the city was limited to a rough inspection of the girders of the roof construction on the occasion of the regular change of use of the hall from ice sports to tennis hall operation and vice versa. This-still

\footnotetext{
${ }^{88}$ LG 2008 RN 138, 452, 460-462.

${ }^{89}$ LG 2008 RN 452.

${ }^{90}$ LG 2008 RN 99.

${ }^{91}$ LG 2008 RN 462.
} 
superficial-inspection, however, was not carried out by skilled experts but by the municipal operating personnel. ${ }^{92}$

Nevertheless, the head of the relevant department of the Bad Reichenhall building authority rated the necessarily superficial inspections as sufficient. ${ }^{93}$ In cross-examination before the Court, the Lord Mayor himself stated that in view of the initially open roof construction it had been assumed that water would not harm the wooden roof structure and its stability. He stated that he and the relevant municipal officials were also convinced that the hall could be considered stable as long as no significant changes were made to the original design. ${ }^{94}$ Court experts stated that this was a common assumption made by authorities when dealing with comparable halls. It was only after the collapse of the ice rink in Bad Reichenhall that regular inspections of the stability of similar constructions were legally prescribed.

With regard to water ingress, however, the Traunstein Regional Court made it clear that the decision not to carry out a review of the load-bearing capacity of the roof was indicative of a "careless handling of the building by those responsible in the city of $\mathrm{B}[\mathrm{ad}] \mathrm{R}$ [eichenhall]". ${ }^{95}$ In view of the water ingress, there would at least have been "reason" to commission an inspection of the glued laminated wooden beams. ${ }^{96}$ After all, "every expert knows that wood constructions, especially glued laminated timber, in connection with frequent water contact, can cause damage to the wood and the construction". ${ }^{97}$ The experts called upon by the Traunstein Regional Court explained that, at least from 2003 onward, a "hands-on" examination of the girder beams would had already revealed the necessity of a stability test which would then have revealed the very defects that ultimately caused the collapse of the hall roof. ${ }^{98}$

In this respect, the non-observance of the repeated complaints about water ingress by those responsible in the Bad Reichenhall City administration can also be defined as a necessary, albeit insufficient, condition for the later collapse of the hall roof. According to the Traunstein Regional Court, obvious water ingress would have been assessed differently by a risksensitive administration. Even if the administration, unaware of the

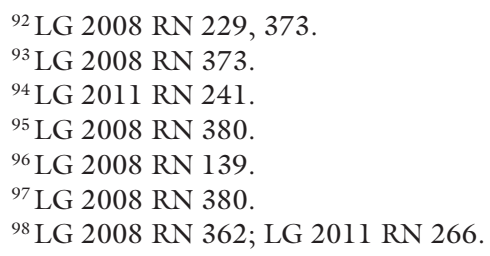


original construction errors which caused the collapse, could not have been fully aware of the consequences of its omission, a risk-sensitive attitude could have prevented the catastrophe of 2 January 2006.

An indirect warning which the city itself had triggered but then ignored arose in the course of the negotiations between the responsible officials of the Bad Reichenhall City administration and a consulted architect in 2002. At that point, the municipality was already considering the closure of the complex and presumably wanted to avoid greater financial expenditure for an expert review of the hall construction. ${ }^{99}$ The architect consulted at the time suggested a comprehensive inspection of the roof structure of the ice rink in order to estimate renovation costs. ${ }^{100}$ Such an investigation would very probably have revealed the existing design and construction errors. The city administration's decision to dispense with this investigation is therefore a further necessary condition for the occurrence of the catastrophe of 2 January 2006.

In its first ruling, the one of 2008, the Traunstein Regional Court emphasized the serious consequences of the risk-blind decisions of those responsible in the city of Bad Reichenhall. They pertained to the indifference to the complaints about the continued water ingress and the decision not to carry out a thorough in-depth inspection of the roof construction. The Court stated in remarkable clarity that even if experts would have performed a thorough inspection according to due diligence standards this would not have changed the negligent attitude of the Bad Reichenhall municipal administration which was driven by the desire to save refit costs to be spent for a building whose closure and demolition was envisaged anyway ${ }^{101}$ - a diagnosis that was confirmed by a municipal official in crossexamination before the Court. ${ }^{102}$

A mentality of municipal officials of accepting risks to the life and limb of the hall users was reflected in the lack of response to the warnings in the 2001 and 2002 reports and, to a lesser extent, in the indifference regarding the water ingress and the recommendation of an architect consulted in 2002 who suggested an in-depth inspection of the roof structure. That mentality came to bear even on the day of the disaster itself.

\footnotetext{
${ }^{99}$ LG 2011, RN 163-165, 270-271.

${ }^{100}$ LG 2011 RN 181, 271.

${ }^{101}$ Cf. LG 2008 RN 373-406, 462, 482.

${ }^{102}$ LG 2008 RN 396, 411.
} 
Table 5.1 Contributing Factors (CF) and Necessary Conditions (NC), collapse of Bad Reichenhall Ice Skating Rink

NC1 Design error and faulty construction of the ice skating rink roof, 1971-1973.

NC2 Omission of the engineer in charge to apply for a special permit for the installation of wooden girders with an extended length; omission to check on the type of glue used in the erection of the roof, 1973.

CF1 Improper documentation of structural engineering details and calculations.

NC3 Installation of exhaust air systems of the hall roof without building permit and without checking on relevant calculations of the roof statics, 1977.

NC4 Failure to follow the recommendation of an expert opinion of July 2002 to conduct an in-depth inspection of the whole roof, January 2003.

NC5 Purposeful omission of the Lord Mayor to implement the decision of the municipal parliament of June 2005 to renovate the hall complex.

CF2 Continuous carelessness and neglect of maintenance despite visible signs of water ingress.

On 2 January 2006, the relevant official of the Bad Reichenhall building authority was in telephone contact with the facility manager of the ice skating rink and indoor swimming pool who called him because of the heavy snowfall and a possible shut-down of the hall. While the decision was made to close the ice skating rink at 4:00 PM, the official did not order any special measures. The Court emphasized that the official of the building authority "obviously had no idea how much snow load the considerably damaged structure of the swimming pool roof could withstand". ${ }^{103}$ Hence a vicious circle of general neglect: The expert opinion obtained in 2003 at conspicuously low costs had determined that the entire hall was in "generally good" condition. The Court stated that the city should not have interpreted this as a reliable statement about the condition of the roof structure of the ice rink because of the low expert fee of just 3000 Euros and the resulting limitation of the scope of the inspection. Accordingly, the building authority's knowledge about true condition of the ice skating rink roof was limited too. Consequently, the building authority official, when called by the facility manager on site at 3:15 PM on 2 January 2006, saw no reason to evacuate the ice skating rink immediately (Table 5.1).

${ }^{103}$ LG 2011 RN 279. 


\subsubsection{Causal Mechanisms}

Constitutive for the political and institutional environment of the decisions that led to the collapse of the roof of the ice skating rink and the death of fifteen people, among them twelve children, was a conflict of interest within the city administration of Bad Reichenhall, which in itself was not unusual. ${ }^{104}$ As the owner of the hall, the city of Bad Reichenhall was interested in low maintenance costs; as the building authority, the city was supposed to be interested in the safety of infrastructure and its users. Prioritizing human safety over saving maintenance costs was the natural duty of the officials in charge. So it was decisive that the Lord Mayor set the wrong priorities.

From the basic conflict of interest within the City administration resulted further situational mechanisms. One pertained to information asymmetries and the control or principal agent problems that arose both in the relationship between the City administration and the expert consulted in 2003 and between the municipal parliament and the administration, especially the Lord Mayor himself. For its part, the city administration had to rely on the expert's assessment while the municipal parliament had to rely on the Lord Mayor as far as the comprehensive renovation of the hall complex was concerned which the parliament had agreed-upon on 14 June 2005. It was probably beyond the imagination of municipal parliament key-figures that the Lord Mayor not only had deliberately restrained the scope and precision of the expert inspection in 2003 and thus was acting on the basis of inadequate information but that he also was determined to obstruct the parliamentary decision anyway.

The Lord Mayor of Bad Reichenhall as the administrative key-figure was not only formally responsible but also a particularly committed decision-maker. According to the standards of due process and diligence in a matter of human safety he should have recognized and neutralized the detrimental effects of conflicting perspectives and interests within the municipality. Instead, his absolute priority was an urban planning intention of shutting down and dismantling the complex of the ice rink and indoor swimming pool altogether. So he used his power to politicize what should never have politicized which was the factual assessment of physical

${ }^{104}$ Cf. James D. Thompson: Organizations in Action: Social Science Bases of Administrative Theory. With a new preface by Meyer N. Zald and a new introduction by W. Richard Scott, London and New York: Routledge 2017 [1967], 132-143. 
condition of the hall roof. ${ }^{105}$ The city's building authority did not only not mitigate the Lord Mayor's course of action but rather implemented its detrimental consequences at the expense of the safety of the users of the ice skating rink.

The mechanisms promoting the one-sided determination to save costs at the expense of safety drove the city administration's action. This was reflected in the indolence vis-à-vis regular reports from users and operating personnel on water ingress. What is more, expert opinions submitted in 2001 and 2002 and the warning notices contained therein were not taken seriously. They pertained to the condition of the canopy of the hall, to fire protection deficiencies and presumed insufficient load-bearing capacity of the indoor swimming pool roof. The question is to what extent these omissions were intentional or the result of incompetence.

What the investigations of the Traunstein Regional Court revealed was that concerns about actual safety risks were never raised within the Bad Reichenhall city administration. A risk-sensitive administration would have taken seriously the recommendation of the expert consulted by the city in 2002 to carry out an in-depth inspection of the ice skating rink roof. Permanently risk-increasing behavior despite warning signs is not uncommon though. It has been classified in the literature "normalization of deviance": Deviations from due diligence or just risk mitigation standards can become entrenched as long as there are no catastrophic consequences. ${ }^{106}$

The capping of the expenses for the expert opinion at 3000 Euros in 2003 indicates that the building authority had not at all been aiming at an in-depth inspection of the roof of the ice rink as had been recommended a year earlier. The city administration might nevertheless have expected a statement on the roof that somehow responded to the expert recommendation of 2002 without, however, substantially doing justice to it. ${ }^{107}$ In this scenario, which points to controlled and intentional inaction,

${ }^{105}$ For the phenomenon of power in organizations and its use to exert pressure on the supposedly a-political "operative core" cf. Henry Mintzberg: The Power Game and the Players. In Steven J. Ott, Jay M. Shafritz and YongSuk Jang, eds., Classic Readings in Organization Theory. Belmont: Wadsworth 1983, 330-337.

${ }^{106}$ Diane Vaughan: The Dark Side of Organizations: Mistake, Misconduct, and Disaster. Annual Review of Sociology 25 (1999): 271-305.

${ }^{107}$ This was one of the suppositions of the Federal Supreme Court in its ruling of 2010 (BGH 2010 RN 85). On symbolic problem solving and the interest in ignorance about it cf. Wolfgang Seibel: Successful Failure. An Alternative View on Organizational Coping. 
the relationship between the city administration and the expert could not be interpreted as a conventional principal-agent-relationship. The relevant literature assumes that the "principal", i.e. the client, has an interest in reducing information deficiencies. ${ }^{108}$ However, the capping of the funds for the expert opinion commissioned in 2003 shows that the Bad Reichenhall city administration was not interested in complete information at all.

Finally, it is also characteristic of the irresponsible behavior of the Bad Reichenhall municipal leadership that it, as the Lord Mayor had to admit before the Traunstein Regional Court, ${ }^{109}$ deliberately ignored the decision of the municipal parliament which had decided on 14 June 2005 to fundamentally renovate the ice rink and indoor swimming pool. This purposeful omission was due to the Mayor's urban planning ambitions part of which was to demolish the hall complex altogether. The administration therefore made policy on its own initiative not only at the expense of the municipal parliament but above all at the expense of hall user safety. In the municipal parliament itself, however, no one has apparently insisted on the implementation of the decision of 14 June 2005. Local policy makers were unaware of the expert opinions solicited by the building authority since the reports of the experts had not been submitted to the municipal parliament. ${ }^{110}$

The mechanisms which created an incentive structure for the actions and omissions of the Bad Reichenhall city administration to downplay safety issues and, in contrast, upgrade aspects of urban planning and cost savings, can be defined as 'situational' in nature. One contribution to this constellation was the information deficits of the city administration with regard to the original construction defects. These situational mechanisms formed opportunity structures or permissive conditions but they obviously did not result in imminent risks for the safety of the hall complex. Rather, these mechanisms represented standard risks that could have been

American Behavioral Scientist 39 (1996): 1011-1024. On delegation and diffusion of responsibility see Björn Bartling and Urs Fischbacher: Shifting the Blame: On Delegation and Responsibility. The Review of Economic Studies 79 (2012): 67-87.

${ }^{108}$ Cf. George A. Akerlof: The Market for 'Lemons': Quality Uncertainty and the Market Mechanism. Quarterly Journal of Economics 84 (1970): 488-500; Michael C. Jensen and William H. Meckling: Theory of the Firm: Managerial Behavior, Agency Costs, and Ownership Structure. Journal of Financial Economics 3 (1979): 305-360.

${ }^{109}$ LG 2011 RN 270.

${ }^{110}$ LG 2011 RN 278. 
brought under control by appropriate countermeasures. Which, however, did not happen. Instead, the Bad Reichenhall city administration was distinctly negligent in handling risks to life and limb of hall users despite continued indications of possible construction defects. This concerned water ingress, the canopy roof of the hall complex, flawed fire protection and defects of the secondary (non-structural) parts of the swimming pool hall roof. In addition, an expert had recommended to the city in 2002 to conduct an in-depth inspection of the roof structure of the ice rink. However, the city did not commission such an inspection.

At the action-formation level, therefore, no classic principal agent relationship existed: Contrary to the relevant theory, the municipal leadership was not interested in detailed information about the condition of the hall complex including its roof construction. On the one hand, organizational myopia $^{111}$ occurred due to the long-term negligent handling of the hall complex by the city administration. On the other hand, some sort of expert opinion was sought by the building authority but the comparatively low remuneration of 3000 Euros left doubt if this was just a placebo measure in order to avoid a costly renovation of a building whose demolition was envisaged anyway. Which would have been a case of deliberate ignorance. ${ }^{112}$ One way or another, the behavioral pattern of negligence was accentuated by the targeted obstruction of the decision of the municipal parliament of June 2005 to fundamentally renovate the hall complex which contradicted the urban planning ambitions of the Lord Mayor.

Nevertheless, the question remains if the collapse of the roof of the ice rink on 2 January 2006 could have been averted at the very last moment. However, it became apparent even on that very day that the lack of risk awareness was deeply engrained so that a timely shut-down and evacuation of the ice rink was not initiated. The facility manager of the ice skating rink, worried about the heavy snow fall, was told by the relevant official of the building authority to wait until 4:00 PM to close the hall. This instruction was issued although the official, according to the Traunstein Regional Court, had not the "slightest idea" of the actual load-carrying capacity of the hall roof (Fig. 5.2). ${ }^{113}$

${ }^{111}$ Maurizio Catino: Organizational Myopia. Problems of Rationality and Foresight in Organizations. Cambridge: Cambridge University Press 2014.

${ }^{112}$ Wolfgang Seibel: Successful Failure.

${ }^{113}$ LG 2011 RN 279. 


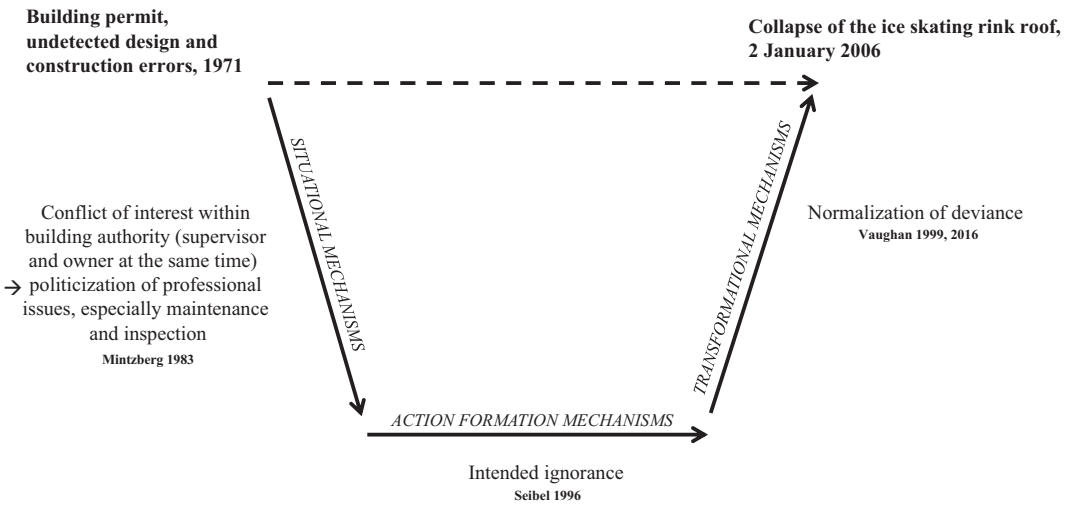

Fig. 5.2 Causal Mechanisms, Collapse of Bad Reichenhall Ice Skating Rink

Open Access This chapter is licensed under the terms of the Creative Commons Attribution 4.0 International License (http://creativecommons.org/licenses/ by $/ 4.0 /$ ), which permits use, sharing, adaptation, distribution and reproduction in any medium or format, as long as you give appropriate credit to the original author(s) and the source, provide a link to the Creative Commons licence and indicate if changes were made.

The images or other third party material in this chapter are included in the chapter's Creative Commons licence, unless indicated otherwise in a credit line to the material. If material is not included in the chapter's Creative Commons licence and your intended use is not permitted by statutory regulation or exceeds the permitted use, you will need to obtain permission directly from the copyright holder.

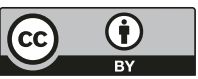

